\title{
Balkanologie
}

Balkanologie Revue d'études pluridisciplinaires

Vol. IV, $n^{\circ} 2 \mid 2000$

Volume IV Numéro 2

\section{The Bulgarian Gypsies - Searching their Place in the Society}

Elena Marušiakova and Veselin Popov

\section{OpenEdition}

1 Journals

Electronic version

URL: https://journals.openedition.org/balkanologie/323

DOI: 10.4000/balkanologie.323

ISSN: 1965-0582

Publisher

Association française d'études sur les Balkans (Afebalk)

Printed version

Date of publication: 1 December 2000

ISSN: 1279-7952

Electronic reference

Elena Marušiakova and Veselin Popov, "The Bulgarian Gypsies - Searching their Place in the Society", Balkanologie [Online], Vol. IV, $n^{\circ} 2$ | 2000, Online since 22 juillet 2011, connection on 28 juin 2022. URL: http://journals.openedition.org/balkanologie/323 ; DOI: https://doi.org/10.4000/balkanologie.323

This text was automatically generated on 17 December 2020 .

(c) Tous droits réservés 


\title{
The Bulgarian Gypsies - Searching their Place in the Society
}

\author{
Elena Marušiakova and Veselin Popov
}

1 Even a superficial acquaintance with the Bulgarian Gypsies gives us some impression of the great variety of Gypsy communities (some of whom do not have a Roma identity) in the country. There are traditional communities (nomads or sedentary) with preserved old trades, language and ethnic and cultural characteristics, as well as communities who have integrated in the surrounding population and are relatively well-educated and socially active. In order to have a better understanding of the present day situation of the Gypsy minority in Bulgaria we have to consider their basic ethnic and social parameters and ethnic and cultural features, as well as their place in society from a historical point of view ${ }^{1}$. Based on the above the present day problems of Bulgarian Gypsies and the main trends of development of the Gypsy community become clear.

2 The first wave of large-scale settlement of Gypsies in Bulgarian lands can be traced back approximately to the period of the 12th-14th c., some earlier contacts are also possible (as early as the 9th century according to some scholarly opinions). Processes of sedentarization in the towns and villages were active among a part of the Gypsy population in the Ottoman Empire (15th-19th c.), others were still living as nomads and had preserved the old trades. A new type of semi-nomadic lifestyle also emerged at the time (Gypsies with a winter residence and an active nomadic season within the regional boundaries). In the 17th and 18th c. a great number of Gypsies, leaving the Danubian principalities (Wallachia and Moldova), entered the Ottoman Empire (the Second Gypsy migration wave in Bulgarian lands). New waves of Gypsy groups came to Bulgaria in the second half of the 19th c. and the beginning of the 20th c. from the principalities after the end of Gypsy slavery (the Third Gypsy migration wave in Bulgarian lands). The migration of Gypsies from neighbouring countries (mainly Rumania and Greece) continued until the 20th c. and was usually related to the change of country borders in the wars (the two Balkan wars, W. W. I and W. W. II).

3 The Bulgarian Gypsies, like Gypsies around the world, are not a homogeneous community. They are divided into many internal subdivisions - separate groups, 
metagroup units and subgroup divisions. All Gypsies in Bulgaria belong to the Roma stream and can be classified on the basis of various criteria - language (or dialect), lifestyle, boundaries of endogamy, professional specialisation, time of settlement in Bulgaria, etc. The combination of these criteria reflects on identity structure and gives the complete picture of the state of Gypsy ethnos. This picture is by no means a static and unchangeable one, it used to be different and will yet be different in other periods of history and its present situation is reflected in our article.

The metagroup community of settled Gypsies or "Yerlia" is the most numerous and varied one. These are the descendants of the first Gypsy migration wave, who speak different dialects of the Balkan group of Romanes. Significant parts of them settled in Balkan town or village mahalas [gypsy quarters] as early as the time of the Ottoman Empire. The community of "Yerlia" is divided into two main subdivisions - Dasikane Roma "Bulgarian Gypsies" (Christians) and Xoraxane Roma "Turkish Gypsies" (Muslims). Within the boundaries of these subdivisions there are some more or less endogamous groups with preserved traditional functions and occupations and awareness of group belonging ${ }^{2}$.

5 At the same time there are large communities who remember the respective group division and the old time occupations, but no longer practice them, the boundaries between groups have been obliterated to a great extent and awareness of belonging has moved to the frame of the bigger community (Dasikane Roma or Xoraxane Roma), with "Bulgarian Gypsies" living mostly in West Bulgaria, and "Turkish Gypsies" in East Bulgaria. These processes are typical mostly for big city mahalas, where the memory of old group division is weak. In some instances, especially after a number of name and religion changes (such as those in Sofia) community awareness can be on a still higher level (only as Yerlia). The ethnic identity here, as in the above example, is within the metagroup.

6 There is another big subdivision of the Gypsy community in Bulgaria which belongs almost entirely to the Yerlia framework today. This is the community of "Vlaxichki" [Wallachian] Gypsies (an appellation used in Western Bulgaria) or Laxo (Laxoria, Vlaxoria - used in Eastern Bulgaria). They use dialects of Romanes which belong to the Old Vlax dialect group. They arrived from Wallachia with the second wave of migration. They used to be nomads with group divisions into Sitaria (Sieve-makers), Reshetaria (Cullender-makers), "Zagundzhia", etc., who gradually became settled in the 1920's and 1930's (some even later) mostly in urban Gypsy mahalas, some changed their religion (those in Eastern Bulgaria are now Moslems) and gradually joined the existing metagroup communities (Dasikane Roma and Xoraxane Roma). Today co-existence between Yerlia and "Vlaxichki" Gypsies (Laxo) and intermarriages are common, but the different group origin is still remembered, there are also some differences in appearance, some cultural and behavioural specifics, which give them a special place in the general metagroup frames of the communities they have entered.

7 Some parts of these communities gradually become differentiated on the basis of their preferred ethnic identity such as some Muslim / "Turkish" Gypsies who have lost most of their group specifics and are often bilingual (speaking Turkish and Romani) or entirely monolingual (speaking only Turkish). They live primarily in East Bulgaria and prefer to introduce themselves as Turks or only as milliet (i.e. a nation). Similar are the examples of the Dzhorevtsi (mules) who have a preferred Bulgarian awareness and the 
Agupti in the Rhodope mountains, who stand apart from the other Gypsies and have almost blended in with the local Turks and Bulgarian Muslims (the so-called Pomaks)

8 A second major and very distinct metagroup community among Bulgarian Gypsies is the one of Kaldarasha / Kardarasha, descendants from the third wave of migration. They are former nomads (until 1958) and are now scattered all over the country, living mostly in villages and small towns and less often in bigger towns. They use New Vlax dialect of Romanes. They are internally divided into differentiated subgroups ${ }^{3}$. All Kardarasha are strictly endogamous within the wider boundaries of the community as a whole.

9 The Thracean Kalaydzhia (Tinsmiths) have a very specific place between the two major metagroup societies (Yerlia and Kardarasha). A number of criteria, such as semi-nomadic lifestyle, strong endogamy within the boundaries of their community, primary role of group identity, etc. make them similar to the Kardarasha, while their language belongs to the groups of old Vlax dialects. They live now mostly in villages scattered all over the Thracea plane, and keep their distance from the other subdivisions of the Gypsy community 4 .

10 A third major and distinct metagroup community is the one of Rudara (called Vlax [Wallachian] Gypsies or Vlaxs by the Bulgarians). Its members speak a dialect of Rumanian and have a preferred Vlax or "old Rumanian" ethnic identity. Until recently Rudara were nomads who had spread around the world during the "great Kelderara invasion". This community consists of two main subdivisions of Lingurara (spoonmakers) who make wooden goods; and Ursara (bear and monkey trainers) and is internally divided into regional sub-divisions ${ }^{5}$. The boundary of endogamy is within the greater Rudara community. Rudara live all over the country, mostly in villages and small towns in their own mahalas.

11 The question of how many are the Gypsies in Bulgarian lands in each period of history has never been answered unequivocally. The date from official population censuses differ quite significantly, at least two or three times, from the actual situation, which is best seen upon comparison with other data from unofficial censuses. One such census of the Ministry of Internal Affairs in 1989 registered 576927 Gypsies, while the National census of population and housing stock on December 41992 registered 313396 people who had declared themselves as Gypsies, out of whom the Gypsy language is a mother tongue for 310425 people $^{6}$. We estimate the number of people of Gypsy origin in Bulgaria as being approximately 700-800 000. Another question altogether is how many of them, for various reasons, would like to declare themselves Gypsies.

Unfortunately we have to admit that there is no information on the number of Gypsy groups and their major subdivisions. We can only make a general approximate estimation to give an idea of the current internal distribution within the Gypsy community. There is no doubt that more than half of the Bulgarian Gypsies belong to the Yerlia community (including the Laxoria who have joined it). Xoraxane Roma are more numerous than Dasikane Roma. As far as the other communities are concerned, we can say that Rudara are slightly more numerous than Kardarasha. 


\section{Social patterns before WW2}

13 The centuries of coexistence between Gypsies and the surrounding population brought about the borrowing of certain patterns of social organisation from the macrosociety.

14 The Gypsies in the Ottoman Empire had a special place in the overall social and administrative organization of the Empire. Despite the population division into two main categories - The faithfuls (Moslem) vs. Raya (gentiles) - Gypsies had their own, specific dual status outside these two categories. They were differentiated according to the ethnic principle (something quite unusual for the Ottoman Empire) with no sharp distinction between Muslim and Christian Gypsies. All were tax paying subjects of the Empire, a part of its legislation and with a specific place in its social structures. As a whole Gypsies were actually closer to the subordinated local population, with the exception of some minor privileges for Muslim Gypsies ${ }^{7}$.

At the time of the Ottoman Empire, as early as the Middle Ages, the Gypsies gradually became an integral part of society (despite their lower social status and the attitude of the population towards them). There was a wide-spread sedentarisation of Gypsies in the towns (where they did unqualified labor or worked as craftsmen) and in the villages (where they often make their living from farm work). When the first textile factories were founded in Bulgaria (in the first half of 19th century in Sliven) most of the workers were Gypsies. The Gypsy nomads (or rather semi-nomads) were much less in number than the sedentary ones, nevertheless they also had a fixed residence and civic duties. All of the above contributed to the development of the processes of social integration of the Gypsies and it is no accident that the first timid attempts at civil emancipation of the Gypsy community date back from Ottoman time. One such attempt was the appeal made by Ilia Naumchev in 1867 for the establishment of an independent Gypsy church according the model of emancipational struggle of all Balkan nations back then ${ }^{8}$.

16 After the independent Bulgarian state was established in 1878, the Gypsies began to search for their own place in its social and political structure. On May 31, 1901 an amendment to the Election Law was voted almost unanimously, suspending the right to vote of the Muslim Gypsies (the majority at this time) and the nomads and thus violating the constitutional principles of equal voting rights for all Bulgarian citizens (we have to mention here that the ethnic Turkish and Bulgarian Muslim members of Parliament voted for this law). The first Gypsy conference was convened in Vidin in 1901 as a reaction against this law, and the decision was taken to start a campaign to revoke the law. The Bulgarian lawyer Marko Markov, J.D. and the "tzari-bashi of Bulgarian Gypsies", Ramadan Ali, drafted an elaborate petition, insisting that the Gypsies in Bulgaria should have the same rights as the rest of the population. The petition was submitted to the National Assembly on June 1, 1905. The absence of any answer whatsoever led to the convocation of the first Gypsy congress in Sofia on December 19, 1905 where a new petition was voted with the same demands, brought once again to the attention of the National Assembly. Eventually, the National Assembly voted a new Electoral Law, where the restrictions on the voting rights of the Gypsies were dropped.

17 A new period in the Gypsy movement for civil equality began after the end of World War I, with the establishment of the organisation "Egypt", headed by Shakir Pashov, in Sofia. The organisation was outlawed in 1925 , and was later re-established with the 
name of Istikbal (Future). In 1931 the newspaper Terbie (Education) emerged as the publication of the Gypsy "Mohammedan Cultural Organisation for National Education" with editor-in-chief Shakir Pashov. A conference convened in Mezdra in 1932 made efforts to broaden the nationwide influence of the organisation but after the coup d'état of May 19, 1934 which overthrew the elected government, the organisation was again dissolved and the newspaper suppressed.

During World War II the Gypsies in Bulgaria were not sent to concentration camps or subjects to mass annihilation, as happened elsewhere in Europe, nor are there any documents bearing witness to such intentions ${ }^{9}$. The Gypsies were not mentioned explicitly in the anti-Jewish Law for the Protection of the Nation. The only mention of Gypsies in the official legislature of that time was Decree 4567 of the Council of Ministers (published in the State Gazette of August 29, 1942) :

Jews are prohibited ... from having marital or sexual relations with people of Bulgarian or similar origin, such marriages concluded after this law is enacted with be considered invalid.

Note: The regulation refers to the marriages of Gypsies to people of Bulgarian or similar origin.

There is no information on how this part of the regulation was observed in respect of Gypsies (and if it was ever applied). During the war many Gypsies were gathered for compulsory labour, mainly harvesting or work on roads, railways, and other public utilities. Their free movement in towns was restricted with the excuse that Gypsies were spreading contagious diseases. Some Gypsies joined the anti-Fascist struggle and a few died as partisans or their helpers. The Gypsies in the town of sliven were particularly active. As soon as the first textile factories were established in the 19th c., Gypsies constituted the majority of workers in them and they joined the syndicate and political struggles. On the whole, the number of Gypsies who participated directly in the anti-Fascist movement in Bulgaria, is relatively small, nevertheless this is a certain indication of their place in social life at the time.

\section{The communist authorities and the Gypsies}

Over a relatively short period of time following the communist takeover on September 9, 1944 (the end of the 1940s and the beginning of the 1950s), in unison with the Soviet model, the policy of the new government was to involve the Gypsies actively in the "building of the new life" as an ethnic community with their own identity and equal rights. An "All-Gypsies' Organization against Fascism and Racism and for the Promotion of the Cultural Development of the Gypsy Minority in Bulgaria" was established on March 6 1945, headed by Shakir Pashov. The newspaper Romano Essi (Gypsy voice) made its appearance in 1946, the Gypsy theatre "Roma" was founded in 1947 in Sofia, local branches of the Gypsy organization were formed as sections of the Fatherland Front (a mass public organisation, satellite of the Bulgarian Communist Party) with equal rights. The National conference of the Gypsies in Bulgaria, held on May 2 1948, confirmed its commitment to the policy of the new government.

21 However, this policy was a rather short-lived one. In the 50's the independent Gypsy organisations were abolished and the popular Gypsy leaders were isolated from public life. This marked the shift to a new policy towards Gypsies whose final goal was their 
complete assimilation into the «Bulgarian socialist nation $»^{10}$. A number of efforts were made in order to achieve this goal :

22 - A gradual process of restricted and decreased mention of Gypsies in official documents and mass media (starting from terminological shift when "gypsies" suddenly became "citizens of gypsy origin" and later all naming of Gypsies vanished and only various euphemisms such as "dark skinned citizens", "children who don't speak Bulgarian", etc. were in use), no more state support for the development of Gypsy culture ;

23 - Termination of the processes of "Turkization" of the Gypsies through the obliteration of Islamic elements in their culture, primarily through "renaming" Muslim Gypsies i.e., substituting Bulgarian names for their original Turkish-Arabic ones. This process took place in several stages, beginning in 1962 (after the special Decision A 101 of the Political Bureau of the Central Committee of BCP whose purpose was «to curb the negative tendencies (...) among Bulgarian Muslims, Gypsies and Tartars to identify with the Turks (...) and to enhance patriotic education ») and ending in 1984-1985.

24 - Providing of permanent residence and permanent occupations for all Gypsies. The first step in this direction was the ban on nomadic lifestyle with Decree \# 258 of 17 October 1958, whereby "vagrancy and pan-handling» were prohibited and citizens were obliged « to get involved in labour beneficial to society and to work according to their strength and abilities ».

In the end of the 1970s, following consultations with other socialist countries, Decision \# 1360 of the Secretariat of the Central Committee of BCP of October 91978 specified in detail the general directions in the policy towards Gypsies : «the emphasis should be laid on their involvement in labour which benefits society, on advancement in their education, on improvement in their living standards, on an increase in their consciousness and self-confidence as full-fledged citizens of socialist Bulgaria, on their growing participation in the building of a developed socialist society ». The decree provided for some specific measures, whose practical implementations, however, were meagre, even the opposite of what was intended, notwithstanding the excess of formal reporting. For example, the separated Gypsy mahalas were supposed to be abolished and their inhabitants removed in quarters where they will be surrounded with Bulgarian neighbours, but only 36 out of the 547 existing (thinking mainly of urban ones) were "closed" and some of them sprang up again a couple of years later. Even though the Decision explicitly stated «not to allow the existence of segregated schools » for Gypsies, schools of this kind not only survived but even acquired legal status hidden behind the euphemism « schools for children with low living standards and culture », their goal was to teach « elementary literacy and some professional skills and discipline ».

26 The last phase in the government's special policy towards Gypsies coincided with the "Process of Revival" of 1984-1985, whose goal was the assimilation of Bulgarian Turks through a "scientific proof" of their Bulgarian origin and forcible change of their names. As it proved impossible to apply this approach to the Gypsies, the official position was to deny the very existence of Gypsies in Bulgaria. The authorities considered them officially non-existent - all mention of the Gypsies in public life and the media vanished, and in some places the Gypsy mahalas were hidden behind big concrete walls. 
27 Naturally, such a ridiculous policy yielded no results - the Gypsies did not cease to exist. At the same time efforts were made (despite their mediocre practical implementation and predominance of paper work) to improve the living conditions and elevate the educational standards of Gypsies in order to make them equal citizens. However, for the sake of objectivity we have to say that the overall social development in the socialist era had a few positive results for the Gypsies. Even the ban on nomadic lifestyle was perceived by the Gypsies at the time of its application, and especially from the point of view of today, as a very positive phenomenon - the nomads were given the opportunity to take beneficial credits, to settle somewhere permanently, to build own houses, etc. The standard of living and civil status of the Gypsy community during socialism grew rapidly and significantly as compared to the previous historical period. The Gypsies had permanent employment (unemployment was practically unknown during socialism), their living conditions increased. Many Gypsies succeeded in obtaining a relatively good education, including higher education, with active support from the state. For a certain period of time some layers of the Gypsy community were able to participate actively in the social and political life of the country. These positive trends in the development of the Gypsy community were accompanied by a multitude of unsolved problems. What were the strategic goals of the government in their Gypsy policy were is another issue, but from the point of view of today it is far more important to see what are the impact of this policy on the Gypsy community ${ }^{11}$.

From a historical point of view there are no essential differences in the attitude of the Bulgarian state towards the Gypsies in the two major periods of its development (1878-1944 and 1944-1989). Actually, the basic pattern of the attitude of all Balkan nations towards the Gypsies was not one of initial confrontation but rather an attitude adopted towards a community of a lower status whose members did not deserve special attention provided if "they knew their place" and did not create problems. This explains the fact why for long periods of time the Gypsies were not the focus of any special policy of the state (and whenever such a policy existed it was inconsistent and rather formal, with no tangible results). Actually, any time when the Gypsies became the focus of state policy, they always were the secondary and supplementary target of political decisions addressed to some other minority, other social structures or the society as a whole. For example, the ban on Gypsy organisations in 1925 was ordered with a law whose goal was the abolishment of leftist political powers; the ban of these organisations in 1934 was caused by the attempt to put a stop to the activities of the organisations of the Turkish minority; the restrictions applied to the Gypsies during W.W. II were applied in the context of the anti-Jewish legislature; the ban on nomadic lifestyle was a result of similar bans imposed on nomad shepherds (Karakachans and Aromanians) and followed the principle of settled living for all citizens of the country ; all further actions of the state undertaken in the 1960's, 1970's and 1980's were a part of the attempt for assimilation or chasing away from the country of the Turkish (and Muslim in general) community.

This general pattern of attitude towards the Gypsies which has endured throughout the centuries, explains the processes taking place in our times, after the changes in 1989 until the present. 


\section{Since the « transition period »}

long transition period (which is still going on now), accompanied by permanent social, economic and political crises. The general crisis reflected very strongly on many aspects of the situation of the Gypsies in Bulgarian society. In the economic aspect Gypsies were the first ones to suffer after the changes began. The majority of them were left unemployed in the cities (after factories were closed down) and in the villages (after the collapse of the cooperative farms). Unemployment and the lack of social assistance changed their way of life. Gypsies adapted relatively quickly to the new situation, primarily in the sphere of "grey" [shadow] economy which is a leading one in Bulgaria. We would like to emphasize the latter fact because if one were to believe official statistics or representative sociological data, Gypsies in Bulgaria should not be able to live at all since almost all of them are unemployed, with no registered income, and only a small part of them receive occasional social assistance.

31 At present the Gypsies are implementing various economic strategies. Many Gypsies, mostly in the towns, have become involved with peddling, quite often abroad as well (mostly in Turkey and Yugoslavia). Others rely on being hired for occasional unqualified work, e.g. in construction. Some Gypsies, mostly living in villages, make their living with seasonal agricultural work and gathering of wild herbs and mushrooms. Yet others have gone back to their old traditional crafts, sometimes in a modified version (different kinds of blacksmith services, tinsmith work, weaving of straw mats, baskets and others). Some of these crafts are related to the nomadic lifestyle. There is a large number of transborder labour migrations, especially of the Rudara, who work illegally in the agricultural farms of Greece, Italy, Spain. Some Gypsies, mainly Kardarasha, have won relatively good positions in the sphere of grey business (manufacture of alcoholic beverages, building undertaking, buying and selling of metals or agricultural produce). The overall picture is rather diversified and it depends on a number of factors, including the internal differentiation of the Gypsy community itself.

Considerable changes have also taken place in the sphere of public relations. The economic crisis and political struggles have caused a tension in society, which often leads to a crisis in the inter-ethnic relations. In the beginning of the transition period the Gypsies were a necessary "scapegoat" in the search of people to blame for the social crisis, often going as far as pogroms, murders of Gypsies by skinheads and police violence $^{12}$. Gradually, however, the situation became relatively calmer and the relationships gradually entered their age-old framework. The Gypsies are still discriminated against and are still victims of violence on the level of personal relations and certain everyday situations, as well as on the level of state institutions (mainly the police). However, the predominant pattern in Bulgarian society is the one of despising the Gypsies as an inferior people who have to know their place. Problems usually arise when the Gypsies are no longer willing to remain in this place. Due to their higher civil consciousness the Gypsies now seem to have become more sensitive towards the attitude of discrimination. There are small and unorganised groups of young men who introduce themselves as skinheads and are an imitation of similar movements in the West ${ }^{13}$. The attempt to create a popular movement based on a racist ideology and 
directed against the Gypsies remains on the level of sensations in the media and has no real potential for development.

The Gypsy policy of State institutions and local authorities can be summed up most generally as a denial of active politics and an imitation of activities although the manifestations of this approach differ over the years. In 1991 a new constitution was adopted based on the presumption of individual civil rights. The most frequently cited Gypsy-related excerpt from this constitution is Art. 6, para. 2 which does not allow for " any limitations of the rights or privileges based on (...) ethnic belonging ... » and thus, anytime the problem of minorities have to be solved, the typical reply is that according to the Constitution all Bulgarian citizens are equal and there can be no privileges. In November 1992 the Constitutional Court gave an explanation to the above text allowing for « certain socially justified privileges » for " groups of citizens » in « an unfavourable social situation ", thus encouraging a certain State policy towards Gypsies, although mostly in a narrow socio-economical field.

The situation remained almost unchanged in the system of executive government despite the change of various cabinets and political powers. For a few years there were discussions about having a special body of the Council of Ministers with representatives of various ministries which would realize a coordinated State policy in respect of Gypsies. Finally, in 1994 an Inter-departmental Council on Ethnic Problems was organized. In 1995, with the coming in power of a new government of the Bulgarian Socialist Party (BSP), this council was transformed into Inter-Administrative Council on Social and Demographic Issues, but the Council had no activities whatsoever.

In the beginning of 1997 the new government of the Union of Democratic Forces (UDF) declared a new state approach to the Gypsy issue. A new government body was established - the National Council on the Ethnic and Demographic Issues at the Council of Ministers. For a long time this Council had no tangible activities and this attitude of the state made the Roma organisations take the lead themselves. Human Rights Project initialises and organises the preparation of a framework Programme For Equal Participation of Roma in the Life of Bulgaria by Roma leaders and independent experts ${ }^{14}$. The Programme turned its back on cheap speculation with specific social and economic problems and paid special attention to the major reason for them - the unequal position of the Gypsies in Bulgarian society. Hence the major directions which the state has to follow in order to implement its Gypsy policy - the establishment of State body for fighting discrimination, desegregation of "Gypsy schools", legalising of the existing Gypsy neighbourhoods, access to the national media and others.

The Framework Programme was discussed in detail, supplemented and approved by all Roma organisations in the country at a National Round table in October 1998 and consequently proposed to the government as a basis of its future work. In response to the initiative of the Roma organisations and in view of the then approaching local elections, the government adopted the slogan for integration of the Gypsies through their participation in local governments. The government also tried to impose, with collaboration of an well-known international NGO, its own programme prepared by Spanish experts of the Council of Europe. The Roma leaders rejected the government proposal and following long negotiations an agreement was signed between the Roma organisations and the Council of Ministers on 7 April 1999. The Council of Ministers discussed and approved with a special Decision the Programme proposed by the Roma on its session of 22 April 1999. Until the present, however, the Bulgarian government 
has limited itself to appointing one Gypsy (Yosif Nunev) expert in the National Council and to making a number of statements in the media and at international forums, without implementing any specific activities for the accomplishment of the programme goals.

On the whole, the Gypsy policy of the state can be characterised in brief as a lack of any real desire to change the existing situation. In the instances when for one or another reason the Bulgarian state has to have a position on specific problems related to the Gypsies (such as participation in certain programmes of European institutions) it still prefers to fake activity instead of making use of the existing potential. This situation is not influenced by the differences between political powers because the attitude towards the Gypsy issue has been predetermined by the underlying stereotypes of and prejudice towards the Gypsies in the Bulgarian society.

A new and important factor after the changes in 1989, which influences the development of the Gypsy community, is the rapidly developing non-governmental sector ${ }^{15}$. The non-governmental organisations (NGOs) were created after the changes in 1989 and exist thanks solely to the financial support of different programs and foundations from abroad. The NGOs in Bulgaria had a powerful surge of development and now are one of the few successful sectors of business which follow a Western, and mostly a US pattern of development. The non-governmental sector firmly believes that the problems of the Gypsies are the sponsors' basic priority and that is why they make them part of their priorities. According to information from 1997 from the Association of Bulgarian Foundations and Societies, the organizations which intended to work with minorities (i.e. mainly Gypsies) are more than 1200.

However, one should not be misled by these numbers. Neither the Bulgarian society as a whole, nor the Gypsies themselves have a clear idea about the number of people and organizations "taking care" of them. Most of these organizations remain deliberately semi-legal - they are registered officially and present their "activity" to sponsors from abroad while rigorously avoiding any mention of their activity in the Bulgarian society. The numerous larger-scale projects on civic education, conflict resolution, "open education", sexual literacy, family planning, protection of Gypsy women from violence and others belong to the same type of projects. They usually take the guise of endless courses and seminars which have led to the formation of a small and closed in itself stratum of paid "professionals of the NGO sector" and a small circle of Gypsies who have become professional "seminar attendants". Quite often the activities of the nongovernmental organizations have been used by the State to distance itself from the problems and transfer the responsibility to the non-governmental sector (for example in the homeless children case). There is an enormous danger stemming from the fact that the non-governmental sector often not only does not urge the State to perform its functions, on the contrary - it has made it stay away from the problem.

We can observe with increasing clarity a transfusion of the NGO models of work with those of the state institutions, which often are partners in various European programmes and their interests coincide to the detriment of the Gypsies. Only one example is enough: in spring of 1998 in the town of Lom was held a seminar, where the representatives of government, local authorities and the organisers (one well-known international NGO) proclaimed their success in establishing of model of collaboration for solving of social and economical problems of the Gypsies; only few weeks after 
Roma from Lom who did not receive social assistance money for more than one year tried to self ignite themselves publicly ${ }^{16}$.

In other instances there is a direct clash of interests of the NGO sector and the Gypsy community, such as in the case of segregated Gypsy schools. Several NGOs implement a number of projects on the education of Gypsy children which cannot be implemented if these schools cease to exist.

However, despite the entry of the parasitic "Gypsy industry", the non-governmental sector, and especially the Roma NGOs, still have a contribution to some positive changes in Bulgarian society.

\section{Gypsies' organizations}

After the changes of 1989, Gypsies in Bulgaria were free to express their identity and organise their respective unions. Gradually, various Gypsy organizations began to emerge, influenced by the overall social and political environment.

At the founding conference on March 17 1990, a decision was made to establish a Democratic Union Roma, whose chairman became Manush Romanov. The initial initiative for this union came from the Bulgarian Socialist Party (BSP), however, in the process of acute political conflicts during the so called Round table, Manush Romanov changed its course towards the UDF. At the initiative of the BSP in the eve of the elections in the spring of 1990, alternative local Gypsy organizations began to emerge all over the country, such as, Movement for social and cultural development of the Gypsies, Organization for social development of Gypsies - Ascent, Cultural and Educational Society of Gypsies, Unity, Club of Gypsy intellectuals, and others. The majority of these associations have a vague status and most of them have ceased to function after the parliamentary elections.

For a certain period of time the Gypsy organizations restricted their activities, even though there were three Gypsy members in Parliament at that time - Manush Romanov (UDF), Sabi Golemanov and Peter Alexandrov (BSP). The Gypsy organizations stirred again only in the summer of 1991, when the political conflicts in the country were on the rise and new elections were approaching. Manush Romanov failed completely in his attempt to transform the Democratic Union Roma into a political power. In the autumn of 1991 he left UDF, where he had the unclear status of "observer", because he was ignored in the pre-election coalition.

In the beginning of 1992 the existing Gypsy organizations manifested a certain tendency towards unity, irrespective of their political views. After a number of preliminary meetings, at the so called Uniting Conference in Sofia on October 17 1992, the United Roma Union was created with chairman Vassil Chaprazov. The supporters of the confederate model refused to join the new leadership and declared that they would not dissolve their organizations. Other Gypsy leaders boycotted the conference ${ }^{17}$.

In the beginning of 1993 the leaders of some Gypsy organizations declared a new initiative for a new union whose individual organizations would preserve their independence. On May 8, 1993 the new organization was officially named Confederacy of the Roma in Bulgaria, led by Peter Georgiev. The goal of the Confederacy was to work for the unity and ethnic emancipation of Gypsies in Bulgaria and to « enter the corridors of power », as an officially « non-political organization ». 
Over a fairly long period of time the Gypsy organizations were less active until the parliamentary elections in the autumn of 1994 stirred them again. After long preelection negotiations, some Gypsy leaders were included in the electoral lists of various political parties and unions. However, their places in these lists made their future election almost impossible. The pre-election agreement of Georgi Parushev with the Movement of Rights and Freedoms (MRF), the representative of the Turkish minority, is especially interesting. It gave Gypsies the right to participate in the elections as MRF members in more than one third of the electoral districts (where there is no Turkish population and MFR received no votes), but this did not contribute to Gypsy presence in Bulgarian political life after the elections. Only one Gypsy was elected member of the new Parliament - Peter Georgiev from the BSP (in 1966 Dimitar Dimitrov from Vidin also entered Parliament as a member of BSP and a substituting deputy).

The political crisis in the end of 1996 and the beginning of 1997, as well as the elections in the spring of 1997 stirred the Gypsy organizations anew. They had several meetings in order to prepare a joint political line of action and joint candidates for Parliament. No agreement was reached, some Gypsy leaders were included in the electoral lists of some parties, again in places where the chance of being elected was almost nonexistent, others ran for Parliament as "independent" candidates, but on the whole Gypsies did not obtain any political representation. Consequently, in 1998 Assen Hristov (substituting deputy) became member of Parliament as a representative of UDF.

In the period between 1989 and 1997 some new organizations came into being, all of them pretending to be "national" and to have clear-cut political ambitions. As usual, they are associated with their leaders - Confederacy of Roma in Bulgaria (Peter Georgiev), United Romani Union (Vassil Chaprazov), Democratic Union Roma (Manush Romanov), Federation of the United Romani Communities (Vassil Danev), Romani Union for Social Democracy (Milcho Russinov), Independent Democratic Union Roma (Assen Hristov), Club "Union" (Toma Tomov), Roma Public Council "Kupate" (Agreement) (established in 1997 as a satellite organisation of UDF led by Zlatko Mladenov and Simeon Blagoev). These so called "national" organizations consist mainly of their own leaders and an insignificant number of of activists, they have almost no organizational activities, no political lobby. Their popularity among the Gypsy population in Bulgaria is not very significant.

51 The disappointment in the " political road of development » gave a powerful impetus to the development of the Gypsy NGO sector and lead to its visible «boom ». More than 150 Gypsy NGOs have already been registered and are now functioning. They implement their projects through the financial assistance of various sources, often with incomes which are many times higher than the average Bulgarian standard of living. The few attempts to unite and coordinate the activities of all Gypsy NGOs have finally turned out to be unsuccessful and the Association of Roma NGOs, established by Peter Kostov and headed by Toma Tomov has become a NGO without any contribution for the association of the already existing organisations.

2 A much more promising approach is the one of Human Rights Project - a Gypsy organization established in 1992 as an organization for Gypsy human rights in Bulgaria. This is an organisation which cooperates actively with other organizations in Bulgaria and abroad. In the course of its development it ceased to be a typical human rights organisation and increased the scope of its activities in various directions. Thus it became an organization which is really working for the development of the community instead of merely servicing the world of "Gypsy industry" with its materials. In the 
process of preparation and approval of the framework Programme the Human Rights Project succeeded in achieving an informal association of the Roma organisations, which, despite their numerous contradictions, have united behind common principles and positions, which they have to defend before the Bulgarian government.

Another important question is how these processes influence the life of the Gypsy community. We can say with certainty that at the moment they concern only a limited part of the Gypsy community and only in some locations. Large subdivisions of the community remain virtually unaffected (such as Rudara, great parts of Turkish speaking Gypsies, many traditional Gypsy groups, etc.).

In the beginning the community of Kardarasha stood apart from these processes too. Kardarasha keep well-preserved ethnic and cultural traditions (including internal selfgovernment - the Meshariava or Gypsy court), strong endogamy, and they are relative rich. They are always looking for new economical niches and logically they have come to the idea to turn to the new social activities in the attempt to legalize partially their business and tie it up with public procurement (which is the most profitable type of activity in the present circumstances).

Initially, they sent their representatives to participate in the new system of Gypsy NGOs - for example Vassil Danev, Toma Tomov, Zlatko Mladenov, Alexander Philipov (Rroma Soros Foundation and the Roma Program of the Open Society Fund). Parallel to this, with the help of the media they applied the familiar pattern of "Gypsy kings" (such as Kiril Rashkov "Tzar Kiro"). They experimented with a transformation of the traditional forms of internal self-government (the creation of "Supreme Meshare" headed by Zlatko Mladenov).

It is the Kardarasha community which has become the basis for the new stage in the development of the Gypsy community related to the activities of the Euro-Roma organisation. Its establishment was initiated by Tsvetelin Kanchev - a Bulgarian who has been adopted in the Kardarasha community, a rich businessman and a Parliament member since the autumn of 1997 (initially a member of the Bulgarian Business Block and later a member of the Bulgarian Euro-left). After a lengthy preparation, a founding congress of the National Euro-Roma Association was held in Sofia in December, 1998. It was attended by 3386 delegates of 205 municipal organisations of all regions in the country. This was the first in the history of Bulgaria public event of such scope, moreover, it was the first such event in modern Gypsy history which was not financed by state, political parties, NGO-s or sponsors from abroad, but by the Roma themselves (mostly Kardarasha). The Congress postulated the main principles in the work of the organisation - internal consolidation of the Gypsy community regardless of its subdivisions and independent participation in the political life of the country.

The new organisation has been very active in the preparation for the coming local elections. The establishment of Euro-Roma is a proof of the fact that Gypsies do not need the shelter of somebody else's political umbrella because they can rely on their own power. The existing constitutional ban on parties on an ethnic principle has proved to be ineffective since it could easily be ignored. In 1999 a few other Gypsy political parties also became active in their preparation for the local elections - Democratic Congress Party (led by Ramadan Rashid), Union for Democratic Development (Ivan Kirov) Bulgarian Party "Future" (led by Sabi Golemanov), "Free Bulgaria" Party (led by Angel Rashkov, the son of "Tzar" Kiro) and small Rudara Party "Political Party Democratic Movement 
'Rodoliubie'” (recently created and led by Ivan Kostov - a member of Rudara community ) .

58 This stirring up of the Gypsy parties frightened the government which reciprocated with a strike against the most popular organisation by depriving Tsvetlin Kanchev of Parliamentary immunity in the summer of 1999 in the eve of the coming local elections, and detaining him under charges of criminal acts, which the Bulgarian public opinion does not take seriously (moreover, there was a similar situation with Kiril Rashkov, who was detained for a few months following ridiculous charges which were not proven).

The desire to try to achieve economic power and political influence through political representation however could not be destroyed more.

The empty slot left by Euro-Roma was partially filled by the Free Bulgaria party whose election campaign relied on the principle of Roma voting for Roma and milliets voting for milliets. The results of the local elections (October 1999) were to a great extent a shock for the Bulgarian society. The Free Bulgaria party received 52300 votes and 83 municipal counsellors and was formed as a political power among the top ten ones. Euro-Roma had 56 municipal counsellors and all Gypsy parties (individually or in various local coalitions) received about $2 \%$ of the votes and about 200 municipal counsellors and key positions in a number of municipal councils, as well as several mayors (in bigger villages). Thus the Roma and their parties have become an important factor in the country's modern political development and only the future will show what the further development of these processes will be ${ }^{18}$.

A specific variant of the quest for another way of community development, different from the already mentioned ones, is the entrance of different Evangelical churches among the Gypsies in Bulgaria. These doings are not totally new, between the two World Wars the first Evangelical churches were built in Gypsy neighbourhoods and though limited, their work never stopped. After the changes in 1989, the already established churches in Bulgaria were joined by a number of new ones, whose activity is directed mainly toward Gypsies. Gradually the Gypsy church communities became differentiated according to the ethnic principle, they elected their own pastors, they began to build their own churches in the Gypsy neighbourhoods and now are only formally related to the church communities. At present many Bulgarian Gypsies have been attracted to the "new churches", moreover, there is a process of registration of an independent Roma church, headed by Boris Borisov from the town of Lom.

The conversion to a new religion is often seen as a possibility to seek a new place in society, to adjust to new conditions, to find an outlet from the crisis in one's own ethnic body ; under Balkan conditions (where ethnic and religious identity are often confused) this could be a way to change one's own ethnic belonging.

\section{Conclusions}

At present it is not easy to outline the tendencies of development of the Roma community, in Bulgaria. In most general terms the situation may be summarised as being a disappointment in the present patterns of development and a search for new perspectives. Bitter experience has convinced the Gypsies that the roads tried so far do not lead to actual results, moreover, do not have the potential to ensure the real 
development of their community. The paternalistic approach of "the good white brothers", which is exactly the same in the activities of the political parties, the State, and the NGO sectors, has placed them in a position of being forever taught and guarded, has destroyed the adaptive mechanisms of the community and in the long run will hinder the natural development of the community. A clear-cut example of the above is that fact that whenever there is an opportunity for independent Gypsy movement or initiatives, such as Euro-Roma or the Framework Programme, the state and the NGOs (with a few exceptions) would use a very lame excuse to unite unanimously against the Gypsies (or refuse to support them. The political parties (and the governments as their derivatives) need the Gypsies as voters, and the NGOs (including those based outside Bulgaria) need a community with problems to care for, protect, defend its rights, etc. However, no one would benefit from the development of a community which will solve (or try to solve) its problems in an independent manner.

It has become clear that the international institutions cannot solve the problems of the Gypsies in the country, and the numerous instances of the "Gypsy industry" sector on various levels (both state and NGO) only confirm this belief. Moreover, the patterns proposed by the West are often inadequate to the situation or lead to the opposite results (as in the examples of Bosnia and Kosovo). The abolishment of restrictions on contacts with Gypsies from abroad shows that the all-Gypsy unity is still only an idea which will take a long time to reach and will become successful if it is based on what the Gypsies have achieved in each country.

It is not easy to say whether the Bulgarian Gypsies will have the strength to take their destiny in their own hands through NGO's or through Political movements, but it is very clear that the idea of such a development already exists and it could hardly be forgotten despite the inevitable disappointments.

\section{NOTES}

1. Marushiakova (Elena), Popov (Vesselin), Gypsies (Roma) in Bulgaria, Frankfurt am Main / Berlin / Bern / New York / Paris / Wien : Peter Lang Verlag, 1997.

2. Among Dasikane Roma such groups are for example: Kalaydzhia (Tinsmiths); Burgudzhia (Gimlet-makers), Koshnicharia (Basket-makers), Dzhambazia (Cattle dealers), etc. ; among Xoraxane Roma - Muzikantia (Musicians); Fichiria, Futadzhia, Koshnicharia (Basket-makers), Dzhambazia (Cattle dealers), Zvancharia (Bell-makers), etc.

3. Such as Zlataria (Grastaria, Nitsuleshi, Serbian Gypsies), Dodolania, Tasmanaria, Zhaplesh, Layashi / Laynesh, Nyamtsuria (German or Austrian Gypsies), etc.

4. The Thracean Kalaydzhia are divided into two subgroups - the Wlaxorya and Salatsi.

5. Such as Monteni, Thracieni, Zagoriani, etc.

6. Rezultati of prebroyavaneto na naselenieto. Tom I - Demografski charakteristiki [The Results from the People Census, Vol. 1 - Demographic Characteristic], Sofia : Natsionalen statisticheski institut, 1994.

7. Marushiakova (Elena), Popov (Vesselin), Gypsies in Ottoman Empire, University of Hertfordshire Press (Interface Collection), 2000. 
8. Marushiakova (Elena), Popov (Vesselin), eds., Studii Romani, Vol. 2, Sofia : Club '90, 1995, pp. 39-45.

9. Marushiakova (Elena), Popov (Vesselin), «Bulgarian Romanies, the Second World War », in Kenrick (Donald), ed., In the Shadow of the Swastika. The Gypsies during the Second World War 2, Centre de Recherches Tsiganes \& University of Hertfordshire Press, 1999.

10. Kenrick (Donald), " Notes on the Gypsies in Bulgaria », Journal of the Gypsy Lore Society, 45 (3-4), 1966.

11. Silverman (Carol), «Bulgarian Gypsies : Adaptation in a Socialist Context » Nomadic Peoples, (21-22), 1986.

12. Bulgarian Helsinki Committee, Human Rights in Bulgaria in 1993[-1998], Annual Report, Sofia, 1994-1999 ; Human Rights Project, Annual Report for 1993[-1998], Sofia, 1994-1999.

13. Zang (Theodor), Destroying Ethnic Identity. The Gypsies of Bulgaria. New York : A Helsinki Watch Report, 1991.

14. Program «For Equal Participation of Roma in Public Life of Bulgaria », Roma Rights in Focus. Newsletter of Human Rights Project, (10) [Special edition], 1998.

15. Marushiakova (Elena), Popov (Vesselin), « Gypsy minority in Bulgaria - literacy, policy and community development (1985-1995)», Alpha 97 (Toronto: Culture Concepts Publishers \& Hamburg : UNESCO Institute for Education), 1997.

16. PER - The Roma in Bulgaria: Collaborative Efforts Between Local Authorities and Nongovernmental Organizations, Princeton : Project on Ethnic relations, 1998.

17. Marushiakova (Elena), « Gruppi ed organizzazioni zingare in Bulgaria e il loro attegiamento verso l' impegno politico », Lacio Drom, 28 (1-2), 1992 ; Popov (Vesselin), « Il problemo zingaro in Bulgaria nel contesto attuale », Lacio Drom, 28 (1-2), 1992.

18. The article includes the period up to the end of 1999.

INDEX

Geographical index: Bulgarie

Keywords: Bulgarie, Tziganes 